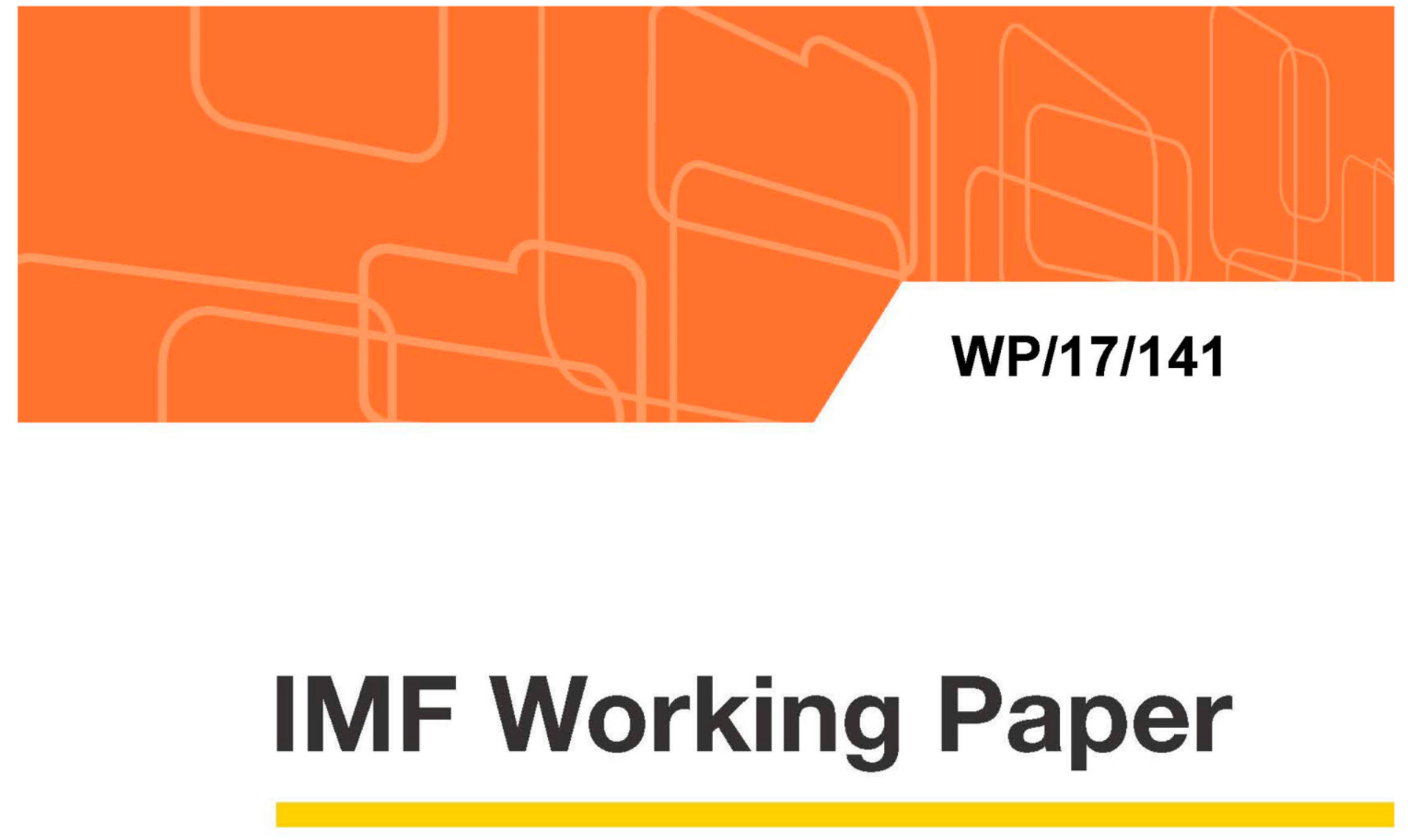

\title{
Who Dares, Wins: Labor Market Reforms and Sovereign Yields
}

by Christian Ebeke

IMF Working Papers describe research in progress by the author(s) and are published to elicit comments and to encourage debate. The views expressed in IMF Working Papers are those of the author(s) and do not necessarily represent the views of the IMF, its Executive Board, or IMF management.

$$
\text { I N T E R N A T I O N A L M O N E T A R Y F U N D }
$$




\title{
WP/17/141
}

\section{IMF Working Paper}

\section{Who Dares, Wins: Labor Market Reforms and Sovereign Yields}

\author{
by Christian Ebeke
}

IMF Working Papers describe research in progress by the author(s) and are published to elicit comments and to encourage debate. The views expressed in IMF Working Papers are those of the author(s) and do not necessarily represent the views of the IMF, its Executive Board, or IMF management.

$$
\text { I N T E R N A T I O N A L M O N E T A R Y F U N D }
$$




\title{
IMF Working Paper
}

European Department

\section{Who Dares, Wins: Labor Market Reforms and Sovereign Yields ${ }^{1}$ \\ Prepared by Christian Ebeke}

Authorized for distribution by Shekhar Aiyar

June 2017

\section{IMF Working Papers describe research in progress by the author(s) and are published to elicit comments and to encourage debate. The views expressed in IMF Working Papers are those of the author(s) and do not necessarily represent the views of the IMF, its Executive Board, or IMF management.}

\begin{abstract}
The paper shows that investors value the adoption of structural reforms by lending at lower cost. The reform-induced reduction of long-term yields is bigger when reforms are initiated in good times and in countries facing high borrowing costs. Importantly, the results show that high-debt countries which launch reforms with some fiscal stimulus do not benefit from a larger and faster reduction of yields. The paper also finds that the social context matters: structural reforms lead to a short-lived overshooting of yields when followed by strikes or lockouts. Controlling for endogeneity issues does not reject the central finding of the paper. These results are economically plausible and confirmed even after using sovereign credit ratings as an alternative dependent variable. These results have two main implications: (i) on average, labor market reforms lower borrowing costs; and (ii) country-specific circumstances also play a role.
\end{abstract}

JEL Classification Numbers: E44; E24; E60

Keywords: Long-term bond yields; Structural reforms; Institutions

Author's E-Mail Address: cebeke@,imf.org

\footnotetext{
${ }^{1}$ I thank Shekhar Aiyar, Angana Banerji, Romain Duval and Davide Furceri, Valerio Crispolti, Alexander Tieman, and Giovanni Melina for insightful comments on an earlier draft. Jesse Siminitz provided outstanding research assistance.
} 


\section{CONTENTS}

$\begin{array}{ll}\text { ABSTRACT_ } & \underline{\mathbf{1}} \\ \text { I. INTRODUCTION } & \underline{\mathbf{3}} \\ \text { II. BASELINE SPECIFICATION AND RESULTS } & \underline{\mathbf{6}} \\ \text { A. Defining structural reform shocks } & \underline{6} \\ \text { B. Local Projection (LP) Method } & \underline{8} \\ \text { C. Baseline results } & \underline{9}\end{array}$

III. STRUCTURAL REFORMS AND LONG-TERM YIELDS: THE CONTEXT

$\begin{array}{ll}\text { MATTERS } & \mathbf{9} \\ \text { A. Non-linear specifications } & \underline{9}\end{array}$

B. Results

IV. ADDRESSING THE POTENTIAL ENDOGENEITY OF REFORM SHOCKS __ $\underline{13}$

V. ONE PLAUSIBLE CHANNEL: IMPROVEMENT IN SOVEREIGN RATINGS _ 15

VI. CONCLUSION $\underline{16}$

VII. APPENDIX 20 


\section{INTRODUCTION}

There are now several empirical findings which are found repeatedly in cross-country studies about the macroeconomic impact of structural reforms on advanced economies: (i) most structural reforms tend to occur in crisis times, (ii) associated costs are frontloaded but the gains come later, (iii) the environment prevailing at the start of reforms matters - reforms implemented in good times and/or with additional support from demand policies (fiscal and monetary) lead to superior economic outcomes. ${ }^{2}$

However little is known about how to bring forward the benefits of structural reforms, an aspect of utmost importance for policymakers and politicians who in most cases fear the disruption which bold reforms can trigger in the short term. ${ }^{3}$ Among the fears are (i) the risk that the short-term contractionary effects of structural reforms will trigger social tensions, (ii) the uncertainty surrounding the future benefits of reforms while short-term uncertainty will be felt immediately, (iii) the cost of building a national consensus for the reform plans, (iv) investors' reaction to the reform package, its implementation, and importantly its feasibility.

On the last point, there is a significant uncertainty about the reaction of investors to reform plans. The uncertainty is related to the direction of the reaction not about the likelihood of a reaction. The same reasons why investors price in other policy decisions (monetary, fiscal, financial) apply to structural reforms. Reforms affect the entire economy and it is likely that investors pay close attention to them. Factors that can influence investors' ex ante views are: (i) the usefulness of the reform proposal, (ii) its political acceptance and implementation, (iii) the economic cost, (iv) the risk of future reform reversal. Each of these factors plays a role in determining the responsiveness of government bond yield to structural reforms.

Each of these factors is inherently correlated with conditions prevailing at the time of the reform adoption. Reforms launched in bad times could be more disruptive (strikes, lockouts, costly politically) and could increase market skepticism about the process. Bond yields can rise rapidly in response, further worsening the country's outlook. Also, political opposition to structural reforms tends to be stronger when the economy is depressed, because voters perceive such measures as likely to further dampen aggregate demand and increase layoffs. ${ }^{4}$

\footnotetext{
${ }^{2}$ On the role of crises and uncertainty on the probability of reforms, see Bonfiglioli and Gancia (2016) and Ranciere and Tornell (2015). On the macroeconomic effects of structural reforms on employment and output, see Bordon et al (2016); IMF (2016); Bouis et al (2012).

${ }^{3}$ Buti et al (2010) discussed how reforms can be achieved successfully while minimizing political risks.

${ }^{4}$ Boeri and Jimeno (2015) argue that structural reforms (e.g. reduction in the excessive protection of workers) can be good if introduced in a boom, but bad if introduced in a slump. According to them, the conditionality imposed on troubled member states by the European Commission or the Troika, new money, or the postponement of a fiscal adjustment program, in exchange for structural reforms - is counterproductive because not enough attention is paid to cyclical aspects.
} 
In contrast, reforms launched in countries already facing higher borrowing costs can lead to a fast reduction in spreads or yields if markets perceive the reform as necessary and appropriate. This suggests that markets may bring forward some of the delayed macroeconomic dividends of reforms by lowering borrowing costs in the short-run, thereby reducing fiscal risks in these economies. Policymakers who implement appropriate reform plans may therefore be rewarded with lower borrowing costs. There is no reason why growth and productivity forecasts should be the only variables to be affected by the adoption of structural reforms. There is also no reason to believe that reform shocks are non-events and therefore neutral on countries' creditworthiness.

This paper uses cross-country data to estimate the dynamic effects of labor market reforms on long-term government bond yields in a sample of advanced economies. The paper largely follows the previous literature that uses OECD indices to (i) identify major reform shocks and (ii) link these reforms to macroeconomic outcomes.

While estimating average treatment effects over time is an interesting exercise in its own right, this paper goes further and proposes an estimation of conditional effects. In other words, the paper asks whether the average treatment effect of structural reforms on long-term yields depends on specific countries' characteristics, such as the strength of social partners, initial macroeconomic conditions including the financial stress level of the country, or the fiscal stance at the time of the reform. It therefore acknowledges that not all reforms are alike.

Empirically, there are a number of challenges in estimating the effects of structural reforms on long-term bond yields. First, the choice of the reform variable (here the "treatment") is crucial. Structural reforms that entail direct fiscal costs (e.g. reforms of labor tax wedge, unemployment benefits, active labor market policies, or even product market reforms that consist of privatizations) will lead to a more challenging econometric exercise because endogeneity concerns are more acute. Indeed, a country which is facing high borrowing costs might be less willing to increase Active Labor Market Policy (ALMP) spending, or to lower the tax wedge, because of the expected worsening of the fiscal position in the short term. The implied negative reverse causality, caused by a country's credit risk, to the reform shock indicator could drive the result, leading to an overestimation of the average treatment effect. It is therefore more appealing to investigate the effect of structural reforms that do not ex ante lead to obvious budgetary impacts. One of these reforms, which is politically difficult to implement, is the reduction in the protection of regular workers: the so-called reform of the Employment Protection Legislation of Regular Workers (EPLR). ${ }^{5}$

\footnotetext{
${ }^{5}$ What we know about EPLR reform from cross-country empirical studies is that (i) it is not very popular and occurs relatively less often in the data than other types of reform, (ii) often it can lead to short-term costs, especially when implemented in bad times or without supportive demand policies. See Bordon et al (2016) and IMF (2016) for interesting empirical investigations.
} 
Second, the endogeneity bias might still remain an issue even after focusing on non-fiscally related reforms (e.g. EPLR reform). Unobservable characteristics of countries or policymakers could play in favor of driving down yields and increasing momentum for reforms. A government (or politician) elected with a mandate to reform, and which has political room to achieve its economic plans is a good example. Some policymakers are courageous, others are not, and their type is only revealed ex post when they are judged by their actions. Therefore, the empirical challenge is to propose an improved identification of the average treatment effect. Ideally, a random sample of reform shocks across countries would be used to get a powerful test of the impact of reforms. In the absence of such a framework, it is necessary to resort to quasi-experimental approaches, in which a model governing the occurrence of a reform shock is first estimated, and then used to identify the effect of reforms on long-term yields in a second stage. ${ }^{6}$ Following Jorda and Taylor (2016) and Bordon et al (2016), this paper makes use of the Augmented Inverted Probability Weighting (AIPW) model to estimate the robust dynamic average treatment effects.

The empirical literature on this topic is surprisingly new. Cardoso and Domenech (2010) showed that structural capacity in countries is negatively correlated with sovereign risk premium. Findlay et al. (2016) arrived at the same conclusion: introducing a set of structural capacity indicators (for labor market, business regulation, institutions, human capital, innovation, and infrastructure) in the regressions explains a higher share of the variation in Credit Default Swap (CDS) spreads. This paper is also very much linked to recent studies examining the effects of structural reforms on fiscal outcomes. Banerji et al. (2017) employed a number of empirical techniques to identify the effects of labor and product market reforms on fiscal variables and found a positive and significant medium-term effect of structural reforms on debt-to-GDP reduction.

Our paper innovates on a number of fronts. First, it extends previous work by estimating the dynamic average effect of reforms on government long-term yields. ${ }^{7}$ Instead of focusing on one coefficient, the paper looks at the effect of reforms over time on sovereign long-term yields and market perception of countries' risk (sovereign credit ratings). Second, the paper proposes an identification strategy aimed at reducing endogeneity concerns. Third, it tests for the existence of any significant conditional factors which might shape the relationship between structural reforms and creditworthiness.

\footnotetext{
${ }^{6}$ Exclusion restrictions (which may be key explanatory factors for an EPLR reform) can include for example initial level of employment protection, electoral cycle, and the educational background of the leader. There are minimal reasons why these factors should impact on long-term yields directly after controlling for other macroeconomic determinants of long-term yields (such as growth, output gap, crises, exchange rate, government debt, and overall balance ratios).

${ }^{7}$ Throughout the rest of the paper, we will use the terms reforms to refer to reforms of employment protection legislations of regular workers, unless it is clarified otherwise.
} 
Beyond its empirical appeal, this paper is part of the broad debate about the macroeconomic effects of structural reforms, including how to minimize their external lags. If markets were to price in the effects of structural reforms, it would provide evidence that some of the fears about the short-term adverse effects of reforms might be (partially) offset by reduced yields on government securities. This paper also contributes to the debate about the net fiscal cost of structural reforms: structural reforms can affect public debt in three ways: through their impact on growth, their impact on fiscal deficit, and their impact on public sector borrowing costs. This paper examines the impact on public sector borrowing costs.

Key findings are as follows: structural reforms (i) do lead over time to a reduction in government bond yields and to an improvement in countries' credit rating, (ii) this effect is stronger in stressed countries, including in countries where reforms are needed the most, and when reforms are launched in good times, (iii) low-debt countries which launch reforms with some fiscal stimulus seem to benefit from a larger reduction of yields, (iv) the social context also matters: structural reforms when followed by social discontent (strikes, lockouts) lead to an overshooting of yields in the short run.

The policy implications are clear. There is a merit in reforming economies in need. Benefits of reforms can be felt earlier than usually thought, including in countries facing high borrowing costs, or in countries complementing reforms with some fiscal support (even though the market will still pay close attention to the debt levels). It is wiser to launch reforms when economic conditions are relatively supportive, and it is crucial to build some political consensus. The markets will appreciate this kind of reform, and will translate the expected future benefits into lower risk premiums.

The rest of the paper is organized as follows: Section II presents the baseline empirical specification which uses local projection techniques to identify the effect of reforms on longterm yields. Section III focuses on conditional factors that strengthen, or weaken, the relationship between reforms and long-term yields. Section IV proposes an identification strategy to better estimate the average treatment effects after reducing endogeneity concerns. Section $V$ discusses the results from alternative specifications using countries' credit ratings as an alternative dependent variable. Section VI offers conclusions.

\section{BASELINE SPECIFICATION AND RESULTS}

\section{A. Defining structural reform shocks ${ }^{8}$}

There are a number of challenges to robustly estimate the effects of structural reforms on countries' creditworthiness or sovereign risk. The choice of the reform variable (here the

\footnotetext{
${ }^{8}$ This section largely draws on Bordon et al. (2016).
} 
"treatment") is crucial. Structural reforms that entail direct fiscal costs (e.g. reforms of labor tax wedge, unemployment benefits, active labor market policies, or product market reforms that consist of privatizations) will lead to a more challenging econometric exercise because endogeneity concerns are more acute. It is therefore more attractive to investigate the effect of structural reforms that do not ex ante lead to budgetary impacts. One of these reforms, politically difficult to implement, is the reduction in the legal protection of regular workers: the so-called EPLR reform.

Structural reform shocks have been identified based on the standard OECD index for employment protection legislation for regular employment contracts. The OECD index ranges from 0 to 6 to capture the restrictiveness of regulation in labor markets. The index is computed as a weighted sum of scores assigned to several underlying criteria. ${ }^{9}$ A higher value indicates more restrictive regulation; thus the introduction of a reform would be represented by a fall of the index. Following Bouis and others (2012), a reform shock in this study is identified as a drop in the OECD index, and the reform variable is defined as a dummy variable which takes a value of 1 when a reform shock is observed.

More specifically, the reform variable used here has the following characteristics:

- Large. A change in the OECD index is considered to be a reform shock if it exceeds two standard deviations of the change in the indicator over all observations. The focus on large episodes allows us to treat them as a shock, and to estimate impulse responses using a dynamic specification. This implies that a series of small reforms over several years may not be identified as reform shocks in this study.

- Discrete. A reform shock is represented by a dummy variable. While this approach ignores the intensity of a reform, it allows identification of the impact of reform shocks using treatment evaluation techniques in which the information on the predicted probability of reform occurring can be taken into account to address the endogeneity issues mentioned earlier. The degree to which reform intensity might be important for the impact of the reform will be discussed below.

- Unsequenced. This paper does not address the issue of reform sequencing. This implies that it also does not capture reform reversals. Focusing on drops in the OECD indicator implies that our analysis will ignore episodes where the OECD indicator increases significantly (i.e. tightening of regulations), even after an initial decline in the indicator. Ignoring the presence of possible later reform reversals could be misleading and could create substantial biases, given that the approach traces the dynamic effects of reform

\footnotetext{
${ }^{9}$ See http://www.oecd.org/els/emp/EPL-Methodology.pdf and http://www.oecd.org/eco/reform/Schemata_PMR.xlsx on the derivation of labor and product market indices, respectively.
} 
over time. However, a careful examination of the sample suggests that in practice there are very few cases of reform reversal.

\section{B. Local Projection (LP) Method}

A model fitting country-level long-term government bond yields to macroeconomic determinants and structural reform shocks is specified. The specification follows Ebeke and $\mathrm{Lu}$ (2016) and Bordon et al (2016) for the cross-country examination of the correlation between long-term yields and the effects of structural reform shocks on employment, respectively. To quantify the dynamic effects of structural reforms on long-term bond yields, the local projection technique (Jorda, 2005) is used. This follows recent work on estimating fiscal multipliers (Auerback and Gorodnichecko, 2013; Owyang, Ramey, and Zubairy, 2013; Jorda and Taylor, 2016) where fiscal consolidation is treated as a shock whose impact on growth over several years is estimated via local projections. ${ }^{10}$ A key advantage of the LP technique is its flexibility. LP accommodates possibly nonlinear or state-dependent impacts easily, which allows for investigation of whether the effects of structural reforms can vary depending on the macroeconomic and social environment.

The LP technique is also flexible enough to robustly control for endogeneity issues, especially when the shock variable is not necessarily exogenous. Below the LP framework will be amended to allow for an identification strategy which uses treatment effect methods, as in Jorda and Taylor (2016), to reduce the risks of endogeneity bias.

The first set of estimations aims to measure the time-varying correlation between reform shocks and changes in government long-term yield, while controlling for basic determinants, cyclical conditions, and time-invariant factors. More formally, the LP specification is as follows:

$$
y_{i, t+h}=\theta_{h} R_{i, t}+\psi_{h}(L) y_{i, t+h-1}+X_{i, t}^{\prime} \Gamma_{h}+u_{i}+\lambda_{t}+\epsilon_{i, t+h}
$$

where $y_{i, t+h}=Y_{i, t+h}-Y_{i, t-1}$, and $Y_{i t}$ is the average government long-term nominal yield in country $i$ observed at year $t$. The model is estimated at each horizon $h=0,1, \ldots, 5$.

$R$ is the reform variable and $\boldsymbol{X}$ is a matrix of control variables. Following the literature on the determinants of government long-term bond yields (Poghosyan, 2014; Ebeke and Lu, 2015), control variables include real GDP growth, output gap, current and lagged inflation rate (which would also capture the reaction of monetary policy, including via adjustments to the policy rate or forward guidance) to ensure that sovereign yields are purged from the inflation variability, lagged government overall fiscal balance-to-GDP ratio, lagged public debt-to-

\footnotetext{
${ }^{10}$ Jorda et al. (2015) also used the LP method to examine the effect of interest rate shocks on housing prices in a large sample of countries.
} 
GDP ratio, exchange rate relative to the US dollar, a dummy identifying banking and financial crises (Laeven and Valencia, 2013), and country and year fixed effects to account for time-invariant country specific factors and common time effects across countries (e.g. the global business cycle, global financial conditions). ${ }^{11}$ Except for the banking crisis dummy, all variables are from the IMF WEO database. The coefficients of interest are $\theta_{h}$ which measures the impact of reforms on the cumulative change in the long-term yield at each horizon starting in year $h=0$ (the year of the reform) up to 5 years after the reform. Driscoll and Kraay (1998) standard errors are computed to account for correlations in the error terms. The models are estimated using a sample of OECD countries (see Appendix I) observed over the period 1985-2015.

\section{Baseline results}

Table 1 presents the cumulative impact of reforms on the long-term government yield for years 0 to 5 . The average effect is not significantly different from zero in years 0 to 2 , suggesting that the average effect might not capture details concerning the short term effects of reforms. However, the estimates become more precise in year 3 , and show a statistically significant reduction of yields adding up to a decline of 140 bps 5 years after the reform. The impact looks plausible. Indeed, the average cumulative reduction in long-term sovereign yields after 5 years is $200 \mathrm{bps}$ in the sample (broadly shared by several countries), leading to a point estimate representing about 70 percent of the unconditional sample average.

[Table 1 about here]

These results are consistent with other empirical work linking structural capacity to sovereign risk premium (see Cardoso and Doménech, 2010; Findlay et al., 2016).

\section{STRUCTURAL REFORMS AND LONG-TERM YIELDS: THE CONTEXT MATTERS}

\section{A. Non-linear specifications}

Several factors can affect the responsiveness of long-term yield to reform shocks. First, because our focus is on labor market reforms (employment protection legislation), there could be heterogeneity related to the institutional characteristics of countries' labor markets. This paper focuses on the degree of unionization (union density) and countries' experience of significant strikes or lockouts over the past 5 years. The intuition is simple: reforms launched in a context of high unionization, and/or in countries with a history of strikes, are less likely to pass smoothly, and could lead to strong opposition. They should lead to a smaller

\footnotetext{
${ }^{11}$ There may be other factors that affect long-term yields (e.g. long-term growth outlook, political stability, long-term creditworthiness). Country fixed effects capture these institutional differences to the extent that these factors are time-invariant.
} 
reduction in long-term yield if the market perceives the reform as a risky strategy. Data on union density are from the OECD, and the number of strikes or lockouts is from ILO statistics.

Second, the state of the business cycle can affect the relationship between structural reforms and yields. Structural reforms launched in bad times (low growth, high unemployment, or negative output gap) could increase market skepticism about the process. Yields are less likely to be depressed by the reform given the expected negative macroeconomic effects of reforms in such contexts. Spreads and yields can rise rapidly in response, worsening further the country's outlook. Also, political opposition to structural reforms tends to be stronger when the economy is depressed, because voters perceive such measures as likely to dampen aggregate demand and to increase layoffs. In this paper the effect of reform shocks $R$ is conditioned on the initial position of the cycle measured by the level of growth, the unemployment rate, or the size of the output gap.

Third, reforms launched in countries facing a high risk premium can lead to a fast reduction in spreads or yields if the market perceives the reform as necessary and appropriate. This suggests that markets may bring forward some of the delayed macroeconomic dividends of reforms by lowering borrowing costs in the short-run, and thereby reducing fiscal risks in these economies. The effect of reform shocks $R$ is conditioned on the initial level of longterm yields observed before the launch of the reform.

These hypotheses are tested using the flexibility allowed by the LP method. Following Auerbach and Gorodnichecko (2013), specification (1) is amended to include a non-linear effect of the reform shock dummy interacted with a smooth transition function of each of the conditional factors discussed above (labor market institutional characteristics, business cycle, market perception). The specification is as follows:

$$
\begin{aligned}
& y_{i, t+h}=\theta_{h L} R_{i, t} F\left(z_{i, t-1}\right)+\theta_{h H} R_{i, t}\left(1-F\left(z_{i, t-1}\right)\right) \\
& +\psi_{h}(L) y_{i, t+h-1}+X_{i, t}^{\prime} \Gamma_{h}+u_{i}+\lambda_{t}+\epsilon_{i, t+h}
\end{aligned}
$$

where $F\left(z_{i, t-1}\right)$ can be interpreted as a measure of probability of being in a particular state (low unionization, low propensity to go to strike, low growth, low unemployment, negative output gap, and low yields) in country $i$ at time $t-1$ based on a measure of the state of the business cycle, $z$ i,t. ${ }^{12}$ Following Auerbach and Gorodnichecko (2013), this gives:

\footnotetext{
12 The variable $z$ is normalized to have a zero mean and unit variance.
} 
$F\left(z_{i, t-1}\right)=\exp \left(-\gamma z_{i, t-1}\right) /\left[1+\exp \left(-\gamma z_{i, t-1}\right)\right]$, with $\gamma=1.5$

The inclusion of the transition function helps to derive impulse response functions from reform shock $R$ at each state represented by the smoothing function $F$. X is the same set of control variables used in the previous specification augmented with the smoothing transition function $F$.

\section{B. Results}

\section{Strikes and lockouts}

In Table 2, the conditional effect of structural reforms on long-term yields is shown depending on the propensity of a country to experience strikes (measured by the lagged number of strikes and lockouts)..$^{13}$ The results show that structural reforms launched in countries with a very high propensity to experience strikes (which can ultimately lead to a withdrawal or substantial amendment of the reform proposal, or simply increase the overall uncertainty and political pressure) will lead to an overshooting of the bond yield by $130 \mathrm{bps}$ in the year of the reform (column 1), before yields eventually return to normal levels.

Interestingly, reforms launched in countries without a history of strikes and lockouts lead to an early reduction of yields (starting in year 1) with a cumulative reduction of yields in the fifth year by about 240 bps.

[Table 2 about here]

As a robustness check, the model is re-estimated and the number of strikes and lockouts is replaced by the number of days not worked (data from ILO statistics). The results are qualitatively and quantitatively similar (Table 3).

[Table 3 about here]

\section{State of the business cycle}

In Table 4, the effect of structural reforms on yields depending on the state of the business cycle prevailing at the time of the reform inception is tested. Three measures of the state of the economy are used to check the robustness of the conclusions. First, use is made of the simple measure of real annual GDP growth to define the position in the cycle. The results are shown in Table 4. There is evidence of long-term yields spiking in the first two years after the reform is launched amid weak growth, whereas yields are substantially depressed when

13 The effect conditional on the union density (as a measure of the strength of social partners) is also estimated and the results are broadly similar. 
reforms are launched in good times. Interestingly, the reduction of yields is significantly higher in good times than for the baseline results.

\section{[Table 4 about here]}

The results are broadly similar when the unemployment rate (Table 5), or the output gap (Table 6), are used instead of growth. Yields are reduced when reforms are launched in good times. The cumulative decline in yields reaches about 300 to $400 \mathrm{bps}$ after 5 years. In contrast, there is a robust evidence of yield overshooting when reforms are launched in bad times. These results are consistent with previous literature which emphasized the short-term negative macroeconomic effects of EPL reforms when activity is already weak.

[Tables 5 and 6 about here]

\section{Market correction of priors}

An interesting question is whether implementing structural reforms can lead to a reassessment by the market of a country's sovereign-risk profile. If the market pays close attention to reform shocks, then countries with initially high sovereign risk should experience a much bigger reduction in yields following the implementation of structural reforms. ${ }^{14}$ This hypothesis is tested by conditioning the effect of structural reforms on the initial level of government long-term yield before the reform adoption using the smooth transition function discussed above. The results are shown in Table 7. There is a significant post-reform reduction of long-term yields observed in countries characterized by initially high borrowing costs. This implies that swings in the market's opinion are more likely in countries with an initially subdued outlook, as reflected by long-term yields. Countries that need to demonstrate action (those with high borrowing costs) seem to be rewarded by the market when embarking on difficult structural reforms.

[Table 7 about here]

\section{Fiscal stance and debt}

Reforms do not necessarily happen with a passive fiscal reaction. There are a number of cases where countries embarked on a reform process while complementing the reform with macro-policy support (see Adhikari et al, 2016 for a description of major reform episodes in some advanced economies). The rationale for doing so is that fiscal support could provide incentives for a broader acceptance of the reform, while at the same time dampening the adverse short-term effects reforms might have on aggregate demand. One crucial aspect

\footnotetext{
${ }^{14}$ Presumably, there are diminishing returns to structural reforms, so that countries characterized with lower initial borrowing costs (low risk premium) have less to gain from undertaking further reform than others.
} 
however, is how the level of public debt matters. A fiscal stimulus granted in a context of very high debt might not necessarily help trigger a reduction in yields if the market perceives the fiscal stimulus as risky given the already high debt. In contrast, a fiscal stimulus is likely to be viewed as complementary by the market if debt is relatively low and sustainability risks are assessed as limited. The fiscal stance is measured by the change in the cyclicallyadjusted primary balance and the smoothing function discussed before is used to build the non-linear effects. There is a significant post-reform reduction of long-term yields observed in the presence of an expansionary fiscal stance when public debt is not high (Table 8). However, when public debt is at high levels, yields spike significantly when reforms are launched together with fiscal stimulus, suggesting that immediate debt sustainability concerns overtake possible medium-term benefits of reforms (Table 9).

[Tables 8 and 9 about here]

\section{ADDRESSING THE POTENTIAL ENDOGENEITY OF REFORM SHOCKS}

\section{Baseline Specification}

The non-exogeneity of the reform shocks could potentially bias the results obtained from the LP technique. The LP approach in Sections II and III is used to control for several variables which can jointly affect the probability of reform occurrence and the dynamic of government long-term yields. The above results also attempted to control for time-invariant countryspecific characteristics and common shocks to countries via country and time fixed effects. However, this may not be enough. Countries that do (or do not do) reforms could share other characteristics beyond the variables controlled for above. For example, some countries might elect or appoint leaders with (or without) a particular pro-reform pedigree or views, or leaders less willing to take risks because they fear the uncertain market reaction to reforms. In addition, political factors might play a role and impact on, among other things, the effectiveness of a given reform approach. Previous estimates could also be affected by the fact that reforms of employment protection legislation of regular worker (EPLR) have been implemented with other structural reforms (e.g., tax reforms, product market reforms, including EU or EMU accession) that affected macroeconomic prospects and hence longterm yields (omitted variable bias).

To robustly assess the link between EPL reforms and government long-term yield, the rest of the paper adopts treatment effect techniques, which have been used extensively in micro and medical studies. An alternative approach to address endogeneity is to use an instrumental variable (an exogeneous source of variation) for the reform variable. However, finding such an instrument is not easy, and is particularly difficult with macro data. Instead, the treatment effect approach allows us to implement doubly robust matching estimates (Jorda and Taylor, 
2016) where the treatment group (in this case, countries engaged in reforms) is compared to the counterfactual group.

The method proceeds in several steps. First, policy propensity scores are derived from a latent model which, in our context, explains the probability of implementing a structural reform based on a number of possible factors, including cyclical, structural, and political variables, as well as policymakers' personal characteristics. These propensity scores are then used in the next step to correct for selection bias and to achieve a quasi-random distribution of treatment and control observations via reweighting. ${ }^{15}$ Second, a regression model - the LP model in our context - is used to fit or forecast the long-term yield (at each horizon in our case) in the treatment group and in the control group (countries which did not reform) for a number of determinants to obtain conditional means. Finally, differences in weighted conditional means (where weights are represented by the inverse propensity scores of each observation) at each horizon between the treatment and control groups are calculated and give an approximation of average treatment effects (ATEs).

Specifically, the (locally) semi-parametric efficient estimator, the Augmented Inverse Propensity-Score Weighting (AIPW), is used which adds an adjustment factor to the ATE to stabilize the estimator when the propensity scores get close to zero or one. Jorda and Taylor (2016) use this methodology to estimate the fiscal multiplier, given that consolidation (the treatment) is determined by many factors that also impact growth (the outcome).

While the AIPW approach mitigates concerns about reverse causality, endogeneity concerns related to omitted variable (reform) bias cannot be ruled out fully. This is specially the case when the variables affecting the adoption of EPL reforms may also drive the implementation of reforms in other areas (such as unemployment benefits, product market reform, etc.). While this can be intuitively addressed by plugging into the specification all other possible reforms implemented in the country, there are two key limitations to this strategy. First, it is nearly impossible to successfully control for all reform shocks at once. Second, endogeneity issues (beyond the omitted variable bias) related to EPL may well be related as well to other reforms, making the problem to solve even greater.

\section{Determinants of EPL reforms}

The first stage regression is presented in Table A1 in Appendix. It employs a logit regression to estimate the probability of implementing structural reforms. Following Bordon et al (2016), the probability of structural reforms is explained with cyclical factors (unemployment rate), structural characteristics (2-year lagged level of employment protection of regular workers, union density), political cycle (dummy taking 1 if the next election is at least in 4

\footnotetext{
${ }^{15}$ Weighting by the inverse of the propensity score shifts weight away from the over-sampled toward the undersampled region of the distribution. This shift of probability mass reconstructs the appropriate frequency weights of the underlying true distribution of outcomes under treatment and control.
} 
year-time), crisis variables (current and lagged output loss from banking and financial crises), and a personal characteristic of the policymakers (a dummy taking 1 if the finance minister of the country has an economics degree).

The results show interesting patterns. In the first column, a pooled logit regression is estimated and the results show that an initially high level of labor market rigidity, low union density, distant election calendar, and banking crises are strong correlates of the probability of embarking into labor market reforms. Also countries more prone to appoint tcehnocrats are surpsingly less likely to embark on reforms after controlling for the other factors above. The results are broadly robust to the use of a logit estimator that accounts for the rare occurrence of reforms in the sample (the ReLogit estimator, column 2) and to the inclusion of country fixed effects in a linear probability model (column 3 ).

\section{Robust impact of structural reforms}

The second stage follows the baseline LP model discussed in Section II. The average treatment effect is computed as the difference of the estimated weighted mean change in government long-term yields between the reformers and non-reformers where the weight of each observation is the inverse of the propensity to reform as estimated in the first stage logit regressions.

Table 10 reports the point estimates using the AIPW approach. As discussed before, the model estimates jointly the probability of observing a reform shock and the time-varying conditional means of long-term government yields between the reforming countries and the control group. The average treatment effects (which vary over time) are then calculated by the weighted difference of conditional means (with weights being the inverse predicted probabilities of observing a reform shock) ${ }^{16}$ The results show a statistically significant reduction of yields following the adoption of structural reforms with a bigger reduction of yields than the baseline estimates discussed in Section II. This suggests that neglecting to reduce endogeneity concerns was inducing an upward endogeneity bias: high yield countries have a higher propensity to embark into structural reform processes to "fix" the economy and collect growth and competitiveness dividends in the future. Similarly, market pressure on policymakers to reform can be relatively high.

[Table 10 about here]

\section{One Plausible Channel: Improvement in Sovereign Ratings}

The results so far are based on the negative relationship between reforms and long-term sovereign yields. One channel through which this might occur is through the increased

\footnotetext{
${ }^{16}$ This approach is similar in its spirit to matching on the observables.
} 
market perception's about the country outlook following the implementation of structural reforms. A simple test could consist in examining the effect of structural reforms on sovereign ratings over time. A strong relationship between reforms and a measure of sovereign rating by private agencies would indicate that the reduction in sovereign yields estimated in the paper is partly driven by the positive shift in investors' perceptions.

Following Reinhart and Rogoff (2009), we measure sovereign ratings using the metric from the Institutional Investor dataset. Ratings range from 0 to a 100, rising with increased creditworthiness of the country. ${ }^{17}$ For the purpose of the study, we make use of countryspecific annual averages of bi-annual (March and September) ratings. The models are estimated using the local projection method (baseline), then re-estimated using the AIPW approach as before in an annual frequency. Similar set of control variables as before are included in the model to purge the effects from confounding factors. ${ }^{18}$

The results are presented in Table 11 (baseline) and Table 12 (robust). They do not reject our priors. The positive correlation between reforms and sovereign ratings gradually strengthens quantitatively and statistically in the medium term, before eventually turning statistically significant in the $5^{\text {th }}$ year (Table 11). The impact is large. In Table 12, the models are reestimated using the AIPW which helps dampen endogeneity concerns. The results show a now statistically significant effect of reforms on sovereign ratings starting in the $3^{\text {rd }}$ year and persisting throughout, consistent with the view that the effect is mainly a level-shift in the country's rating.

[Table 11 and Table 12 about here]

\section{CONCLUSION}

On average, structural reforms lead to a non-trivial reduction of long-term government yields and help improve countries' creditworthiness. This is interpreted as investors pricing in the expected long-term benefits of structural reforms which is stronger in certain context well identified in the paper. It is shown throughout the paper that the results are robust and can be amplified or attenuated by conditional factors such as: the state of the business cycle, the strength of social partners, the initial level of financial stress, and the fiscal stance. Overall, reforms are likely to trigger a reduction of long-term government yield when risks of social

\footnotetext{
${ }^{17}$ One clear advantage of this dataset is the availability of numerical sovereign ratings for a large set of countries over a long period of time (starting in 1979).

${ }^{18}$ Additional works on the cross-country drivers of sovereign ratings include Avendano et al. (2011) and Ratha et al. (2011).
} 
discontent are low, in good times, in countries facing high borrowing costs, and in the presence of supportive fiscal policy provided that public debt is not too high.

The policy implications are clear. There is a merit in reforming economies in need, and investors tend to look kindly on reform efforts. The benefits of reforms can be felt earlier than usually thought, including in countries facing high borrowing costs, and those complementing the reform with some fiscal stimulus. It is wise to launch reforms when economic conditions are relatively supportive, and it is crucial to build some political and social consensus. The markets will appreciate and will translate the future benefits into lower risk premiums and higher credit rating. 


\section{References}

Adhikari, Bibek, Romain A. Duval, Bingjie Hu, Prakash Loungani, 2016, "Can Reform Waves Turn the Tide? Some Case Studies Using the Synthetic Control Method", IMF Working Papers 16/171, International Monetary Fund.

Auerbach, Alan J. and Yuriy Gorodnichenko, 2013, "Output Spillovers from Fiscal Policy", American Economic Review, American Economic Association, vol. 103(3), pages 141-46, May.

Avendano, Rolando, Norbert Gaillard and Sebastián Nieto-Parra, 2011, “Are working remittances relevant for credit rating agencies?", Review of Development Finance, vol. 1, Issue 1, pages 57-78, January-March.

Banerji, Angana, Valerio Crispolti, Era Dabla-Norris, Romain Duval, Christian Ebeke, Davide Furceri, Takuji Komatsuzaki and Tigran Poghosyan, 2017, "Labor and Product Market Reforms in Advanced Economies"; Fiscal Costs, Gains, and Support, No 17/03, IMF Staff Discussion Notes, International Monetary Fund,

Boeri, Tito and Juan Francisco Jimeno, 2015, "The Unbearable Divergence of Unemployment in Europe", CEP Discussion Papers dp1384, Centre for Economic Performance, LSE.

Bonfiglioli, Alessandra and Gino Gancia, 2015, "Economic Uncertainty and Structural Reforms", Economics Working Papers 1494, Department of Economics and Business, Universitat Pompeu Fabra, revised Jul 2016.

Bordon, Anna R., Christian H. Ebeke and Kazuko Shirono, 2016, "When Do Structural Reforms Work? On the Role of the Business Cycle and Macroeconomic Policies", IMF Working Papers 16/62, International Monetary Fund.

Bouis, Romain, Orsetta Causa, Lilas Demmou and Romain Duval, 2012, "How quickly does structural reform pay off? An empirical analysis of the short-term effects of unemployment benefit reform," IZA Journal of Labor Policy, vol. 1(1), pages 1-12, December.

Buti, Marco, Alessandro Turrini, Paul Van den Noord and Pietro Biroli, 2010, "Reforms and re-elections in OECD countries", Economic Policy, CEPR;CES;MSH, vol. 25, pages 61-116, 01 .

Cardoso, Miguel and Rafael Doménech, 2010, “The sovereign debt crisis: Structural Reforms and Country Risk", VoxEU, December, 2010.

Driscoll, John C. And Aart C. Kraay, 1998, "Consistent Covariance Matrix Estimation With Spatially Dependent Panel Data”, The Review of Economics and Statistics, MIT Press, vol. 80(4), pages 549-560, November. 
Ebeke, Christian and Yinqiu Lu, 2015, "Emerging market local currency bond yields and foreign holdings - A fortune or misfortune?", Journal of International Money and Finance, Elsevier, vol. 59, pages 203-219.

Findlay, Christopher, Silvia Sorescu and Camilo Umana Dajud, 2016, "Markets are Smart! Structural Reforms and Country Risk", Working Papers 2016-23, CEPII research center.

IMF, 2016, "Time for a Supply-Side Boost? Macroeconomic Effects of Labor and Product Market Reforms in Advanced Economies", Chapter 3 of April 2016 World Economic Outlook.

Jordà, Òscar, 2005, "Estimation and Inference of Impulse Responses by Local Projections", American Economic Review, American Economic Association, vol. 95(1), pages 161-182, March.

, Moritz, Schularick and Alan M. Taylor, 2015, "Betting the house”, Journal of International Economics, Elsevier, vol. 96(S1), pages S2-S18.

, and Alan M. Taylor, 2016, "The Time for Austerity: Estimating the Average Treatment Effect of Fiscal Policy”, Economic Journal, Royal Economic Society, vol. 126(590), pages 219-255, 02.

Owyang, Michael T., Valerie A. Ramey and Sarah Zubairy, 2013, “Are Government Spending Multipliers Greater during Periods of Slack? Evidence from Twentieth-Century Historical Data", American Economic Review, American Economic Association, vol. 103(3), pages 129-34, May.

Poghosyan, Tigran, 2014, "Long-run and short-run determinants of sovereign bond yields in advanced economies”, Economic Systems, Elsevier, vol. 38(1), pages 100-114.

Ratha, Dilip, Prabal K. De and Sanket Mohapatra, 2011, "Shadow Sovereign Ratings for Unrated Developing Countries”, World Development, Elsevier, vol. 39(3), pages 295-307, March.

Reinhart, Carmen and Kenneth Rogoff, 2009, “This Time Is Different: Eight Centuries of Financial Folly", (Princeton: Princeton University Press, September 2009).

Ranciere, Romain and Aaron Tornell, 2015, "Why Do Reforms Occur in Crises Times?" Working Paper. 
VII. APPENDIX

Table A1: Correlates of the occurrence of structural reforms

\begin{tabular}{|c|c|c|c|}
\hline 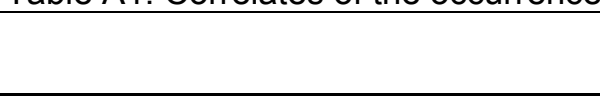 & $\begin{array}{l}\text { Pooled Logit } \\
\text { (1) }\end{array}$ & $\begin{array}{l}\text { ReLogit } \\
(2)\end{array}$ & $\begin{array}{c}\text { LPM } \\
(3)\end{array}$ \\
\hline Unemployment rate & $\begin{array}{c}0.116 \\
(0.993)\end{array}$ & $\begin{array}{c}0.114 \\
(0.990)\end{array}$ & $\begin{array}{c}0.000742 \\
(0.386)\end{array}$ \\
\hline Initial level of employment protection & $\begin{array}{l}1.438^{* * *} \\
(2.867)\end{array}$ & $\begin{array}{l}1.275^{\star * *} \\
(2.582)\end{array}$ & $\begin{array}{c}0.129^{* * *} \\
(3.861)\end{array}$ \\
\hline Union density & $\begin{array}{c}-0.0491^{* * *} \\
(-2.878)\end{array}$ & $\begin{array}{c}-0.0421^{* *} \\
(-2.504)\end{array}$ & $\begin{array}{c}-0.00182 \\
(-1.148)\end{array}$ \\
\hline Election dummy (in 4-year time) & $\begin{array}{l}1.761^{* * *} \\
(2.670)\end{array}$ & $\begin{array}{l}1.647^{* *} \\
(2.537)\end{array}$ & $\begin{array}{l}0.0229 \\
(1.599)\end{array}$ \\
\hline Output loss during banking crises & $\begin{array}{c}0.00430 \\
(0.332)\end{array}$ & $\begin{array}{c}0.00658 \\
(0.516)\end{array}$ & $\begin{array}{c}0.000156 \\
(0.380)\end{array}$ \\
\hline Lagged output loss & $\begin{array}{c}0.0403^{* * *} \\
(3.043)\end{array}$ & $\begin{array}{c}0.0385^{\star * *} \\
(2.957)\end{array}$ & $\begin{array}{c}0.00129^{*} \\
(1.943)\end{array}$ \\
\hline Finance minister has an econ. degree & $\begin{array}{c}-2.869^{* * *} \\
(-3.443)\end{array}$ & $\begin{array}{c}-2.318^{* \star *} \\
(-2.827)\end{array}$ & $\begin{array}{c}-0.0229^{* *} \\
(-2.756)\end{array}$ \\
\hline Intercept & $\begin{array}{c}-7.509^{* * *} \\
(-3.727)\end{array}$ & $\begin{array}{c}-6.863^{* * *} \\
(-3.462)\end{array}$ & $\begin{array}{c}-0.206^{* * *} \\
(-2.827)\end{array}$ \\
\hline Country fixed effects & No & No & Yes \\
\hline Observations & 493 & 493 & 493 \\
\hline Number of countries & 23 & 23 & 23 \\
\hline
\end{tabular}

Note: t-statistics in parentheses. 
Table 1. Effect of Reforms on Government Long-Term Bond Yields (Baseline) Dependent variable: Deviation in bond yields relative to pre-reform year

\begin{tabular}{lcccccc}
\hline & Year 0 & Year 1 & Year 2 & Year 3 & Year 4 & Year 5 \\
\hline & & & & & & \\
Structural reforms & 0.498 & -0.247 & -0.403 & $-0.882^{* *}$ & $-1.432^{* * *}$ & $-1.411^{* * *}$ \\
& $(1.701)$ & $(-0.489)$ & $(-0.616)$ & $(-2.386)$ & $(-3.045)$ & $(-2.814)$ \\
Average change in yields (in pps) & -0.4 & -0.7 & -1.0 & -1.3 & -1.6 & -2.0 \\
Observations & 535 & 535 & 535 & 535 & 510 & 485 \\
Number of countries & 25 & 25 & 25 & 25 & 25 & 25 \\
\hline
\end{tabular}

Note: t-statistics from Driscoll-Kraay standard errors in parentheses.

Additional controls: Lagged change in yields, real GDP growth, lagged output gap, inflation, lagged overall fiscal balance-to-GDP, lagged bilateral exchange rate vis-à-vis the \$US, banking crisis dummy, country and year fixed effects.

${ }^{* * *} p<0.01,{ }^{* *} p<0.05,{ }^{*} p<0.1$. 
Table 2. Effect of Reform on Government Long-Term Yields

Dependent Variable: Deviation in long-term yields relative to pre-reform year

\begin{tabular}{|c|c|c|c|c|c|c|}
\hline & Year 0 & Year 1 & Year 2 & Year 3 & Year 4 & Year 5 \\
\hline Structural reforms, Low strikes & $\begin{array}{c}-0.610 \\
(-0.749)\end{array}$ & $\begin{array}{c}-3.005^{\star * *} \\
(-4.016)\end{array}$ & $\begin{array}{l}-1.893^{*} \\
(-1.796)\end{array}$ & $\begin{array}{l}-1.474^{*} \\
(-2.049)\end{array}$ & $\begin{array}{l}-2.453^{* *} \\
(-2.566)\end{array}$ & $\begin{array}{l}-2.389^{*} \\
(-1.991)\end{array}$ \\
\hline Structural reforms, High strikes & $\begin{array}{l}1.305^{\star *} \\
(2.364)\end{array}$ & $\begin{array}{c}0.809 \\
(1.432)\end{array}$ & $\begin{array}{c}-0.660 \\
(-1.458)\end{array}$ & $\begin{array}{l}-1.023^{* *} \\
(-2.216)\end{array}$ & $\begin{array}{l}-1.154^{*} \\
(-2.038)\end{array}$ & $\begin{array}{c}-0.809 \\
(-1.152)\end{array}$ \\
\hline $\begin{array}{l}\text { Observations } \\
\text { Countries }\end{array}$ & $\begin{array}{c}420 \\
22\end{array}$ & $\begin{array}{c}420 \\
22\end{array}$ & $\begin{array}{c}420 \\
22\end{array}$ & $\begin{array}{c}420 \\
22\end{array}$ & $\begin{array}{c}420 \\
22\end{array}$ & $\begin{array}{c}420 \\
22\end{array}$ \\
\hline
\end{tabular}

Note: t-statistics in parentheses.

Conditional mean controls: Lagged change in yields, real GDP growth, lagged output gap, inflation, lagged overall fiscal balance-to-GDP, lagged public debt-to-GDP, lagged bilateral exchange rate vis-à-vis the $\$ U S$, output loss due to banking crisis and the strike transition function.

${ }^{* * *} p<0.01,{ }^{* *} p<0.05,{ }^{*} p<0.1$. 
Table 3. Effect of Reform on Government Long-Term Yields

Dependent Variable: Deviation in long-term yields relative to pre-reform year

\begin{tabular}{lcccccc}
\hline & Year 0 & Year 1 & Year 2 & Year 3 & Year 4 & Year 5 \\
\hline Structural reforms, Days not worked (Low) & $-1.286^{* *}$ & $-2.427^{* * *}$ & $-1.801^{*}$ & $-1.511^{*}$ & $-2.613^{* * *}$ & $-2.468^{*}$ \\
& $(-2.770)$ & $(-5.899)$ & $(-1.727)$ & $(-1.902)$ & $(-3.148)$ & $(-2.053)$ \\
Structural reforms, Days not worked (High) & $2.215^{* * *}$ & $0.517^{* *}$ & $-0.707^{* *}$ & $-1.046^{* *}$ & $-0.981^{*}$ & -0.667 \\
& $(9.499)$ & $(2.668)$ & $(-2.147)$ & $(-2.175)$ & $(-1.847)$ & $(-0.912)$ \\
& 454 & 454 & 454 & 454 & 454 & 454 \\
Observations & 23 & 23 & 23 & 23 & 23 & 23 \\
Countries & & & & & &
\end{tabular}

Note: t-statistics in parentheses.

Conditional mean controls: Lagged change in yields, real GDP growth, lagged output gap, inflation, lagged overall fiscal balance-to-GDP, lagged public debt-to-GDP, lagged bilateral exchange rate vis-à-vis the \$US, output loss due to banking crisis, and the smooth transition function.

${ }^{* * *} p<0.01,{ }^{* *} p<0.05,{ }^{*} p<0.1$. 
Table 4. Effect of Reform on Government Long-Term Yields

Dependent Variable: Deviation in long-term yields relative to pre-reform year

\begin{tabular}{lcccccc}
\hline & Year 0 & Year 1 & Year 2 & Year 3 & Year 4 & Year 5 \\
\hline Structural reforms, Low growth & & & & & & \\
& $1.082^{* *}$ & 1.545 & 1.334 & -0.382 & -0.186 & -0.230 \\
& $(2.095)$ & $(1.638)$ & $(1.234)$ & $(-0.502)$ & $(-0.424)$ & $(-0.714)$ \\
Structural reforms, High growth & & & & & \\
& -0.532 & $-3.544^{* * *}$ & $-3.572^{* * *}$ & $-2.040^{*}$ & $-3.526^{* * *}$ & $-3.256^{* * *}$ \\
& $(-0.437)$ & $(-3.577)$ & $(-3.738)$ & $(-1.859)$ & $(-4.893)$ & $(-3.994)$ \\
Observations & 535 & 535 & 535 & 535 & 510 & 485 \\
Countries & 25 & 25 & 25 & 25 & 25 & 25 \\
\hline
\end{tabular}

Note: t-statistics in parentheses.

Conditional mean controls: Lagged change in yields, real GDP growth, lagged output gap, inflation, lagged overall fiscal balance-to-GDP, lagged public debt-to-GDP, lagged bilateral exchange rate vis-à-vis the \$US, output loss due to banking crisis, and the smooth transition function.

${ }^{* * *} p<0.01,{ }^{* *} p<0.05,{ }^{*} p<0.1$. 
Table 5. Effect of Reform on Government Long-Term Yields

Dependent Variable: Deviation in long-term yields relative to pre-reform year

\begin{tabular}{|c|c|c|c|c|c|c|}
\hline & Year 0 & Year 1 & Year 2 & Year 3 & Year 4 & Year 5 \\
\hline Structural reforms, Low unemployment rate & $\begin{array}{c}-0.694 \\
(-1.246)\end{array}$ & $\begin{array}{l}-1.887^{* *} \\
(-2.531)\end{array}$ & $\begin{array}{c}-1.173 \\
(-1.061)\end{array}$ & $\begin{array}{c}-0.972 \\
(-1.197)\end{array}$ & $\begin{array}{c}-2.418^{* * \star} \\
(-3.557)\end{array}$ & $\begin{array}{l}-2.499^{* *} \\
(-2.735)\end{array}$ \\
\hline Structural reforms, High unemployment rate & $\begin{array}{l}1.771^{* * *} \\
(4.572)\end{array}$ & $\begin{array}{l}1.245^{*} \\
(1.772)\end{array}$ & $\begin{array}{c}0.160 \\
(0.211)\end{array}$ & $\begin{array}{c}-1.005 \\
(-1.276)\end{array}$ & $\begin{array}{c}-0.203 \\
(-0.426)\end{array}$ & $\begin{array}{l}0.136 \\
(0.215)\end{array}$ \\
\hline $\begin{array}{l}\text { Observations } \\
\text { Countries }\end{array}$ & $\begin{array}{c}535 \\
25\end{array}$ & $\begin{array}{c}535 \\
25\end{array}$ & $\begin{array}{c}535 \\
25\end{array}$ & $\begin{array}{c}535 \\
25\end{array}$ & $\begin{array}{c}510 \\
25\end{array}$ & $\begin{array}{c}485 \\
25\end{array}$ \\
\hline
\end{tabular}

Note: t-statistics in parentheses.

Conditional mean controls: Lagged change in yields, real GDP growth, lagged output gap, inflation, lagged overall fiscal balance-to-GDP, lagged public debt-to-GDP, lagged bilateral exchange rate vis-à-vis the \$US, output loss due to banking crisis, and the smooth transition function.

${ }^{* * *} p<0.01,{ }^{* *} p<0.05,{ }^{*} p<0.1$. 
Table 6. Effect of Reform on Government Long-Term Yields

Dependent Variable: Deviation in long-term yields relative to pre-reform year

\begin{tabular}{|c|c|c|c|c|c|c|}
\hline & Year 0 & Year 1 & Year 2 & Year 3 & Year 4 & Year 5 \\
\hline Structural reforms, Low (negative) output gap & $\begin{array}{l}1.826^{* *} \\
(2.376)\end{array}$ & $\begin{array}{l}1.879^{* * *} \\
(3.479)\end{array}$ & $\begin{array}{l}1.467^{*} \\
(1.726)\end{array}$ & $\begin{array}{l}-0.0914 \\
(-0.136)\end{array}$ & $\begin{array}{c}0.393 \\
(0.700)\end{array}$ & $\begin{array}{c}0.846 \\
(1.645)\end{array}$ \\
\hline Structural reforms, High (positive) output gap & $\begin{array}{c}-1.093 \\
(-0.796)\end{array}$ & $\begin{array}{c}-2.816^{* * *} \\
(-6.582)\end{array}$ & $\begin{array}{l}-2.663^{* *} \\
(-2.240)\end{array}$ & $\begin{array}{l}-1.871^{*} \\
(-2.008)\end{array}$ & $\begin{array}{c}-3.599^{* * *} \\
(-3.178)\end{array}$ & $\begin{array}{c}-4.012^{* * *} \\
(-3.662)\end{array}$ \\
\hline $\begin{array}{l}\text { Observations } \\
\text { Countries }\end{array}$ & $\begin{array}{c}535 \\
25\end{array}$ & $\begin{array}{l}535 \\
25\end{array}$ & $\begin{array}{l}535 \\
25\end{array}$ & $\begin{array}{l}535 \\
25\end{array}$ & $\begin{array}{l}510 \\
25\end{array}$ & $\begin{array}{c}485 \\
25\end{array}$ \\
\hline
\end{tabular}

Note: t-statistics in parentheses.

Conditional mean controls: Lagged change in yields, real GDP growth, lagged output gap, inflation, lagged overall fiscal balanceto-GDP, lagged public debt-to-GDP, lagged bilateral exchange rate vis-à-vis the $\$ U S$, output loss due to banking crisis, and the smooth transition function.

${ }^{* * *} p<0.01,{ }^{* *} p<0.05,{ }^{*} p<0.1$. 
Table 7. Effect of Reform on Government Long-Term Yields

Dependent Variable: Deviation in long-term yields relative to pre-reform year

\begin{tabular}{|c|c|c|c|c|c|c|}
\hline & Year 0 & Year 1 & Year 2 & Year 3 & Year 4 & Year 5 \\
\hline Structural reforms, Low borrowing cost environment & $\begin{array}{c}-0.226 \\
(-0.297)\end{array}$ & $\begin{array}{c}1.755 \\
(1.159)\end{array}$ & $\begin{array}{c}2.900 \\
(1.677)\end{array}$ & $\begin{array}{c}1.272 \\
(1.614)\end{array}$ & $\begin{array}{c}0.693 \\
(0.606)\end{array}$ & $\begin{array}{c}1.073 \\
(1.148)\end{array}$ \\
\hline Structural reforms, High borrowing cost environment & $\begin{array}{c}1.033 \\
(1.091)\end{array}$ & $\begin{array}{r}-1.597^{* *} \\
(-2.216)\end{array}$ & $\begin{array}{c}-2.516^{* * *} \\
(-3.181)\end{array}$ & $\begin{array}{l}-2.104^{* *} \\
(-2.640)\end{array}$ & $\begin{array}{c}-2.509^{* * *} \\
(-2.917)\end{array}$ & $\begin{array}{c}-2.645^{\star *} \\
(-2.674)\end{array}$ \\
\hline $\begin{array}{l}\text { Observations } \\
\text { Countries }\end{array}$ & $\begin{array}{c}516 \\
25\end{array}$ & $\begin{array}{c}516 \\
25\end{array}$ & $\begin{array}{c}516 \\
25\end{array}$ & $\begin{array}{c}516 \\
25\end{array}$ & $\begin{array}{c}491 \\
25\end{array}$ & $\begin{array}{c}466 \\
25\end{array}$ \\
\hline
\end{tabular}

Note: t-statistics in parentheses.

Conditional mean controls: Lagged change in yields, real GDP growth, lagged output gap, inflation, lagged overall fiscal balance-toGDP, lagged public debt-to-GDP, lagged bilateral exchange rate vis-à-vis the $\$ \cup S$, output loss due to banking crisis, and the smooth transition function.

${ }^{* * *} p<0.01,{ }^{* *} p<0.05,{ }^{*} p<0.1$. 
Table 8. Effect of Reform on Government Long-Term Yields

Dependent Variable: Deviation in long-term yields relative to pre-reform year

\begin{tabular}{|c|c|c|c|c|c|c|}
\hline & Year 0 & Year 1 & Year 2 & Year 3 & Year 4 & Year 5 \\
\hline Structural reforms, Fiscal expansion \& Debt $<60$ & $\begin{array}{c}0.658 \\
(1.474)\end{array}$ & $\begin{array}{l}-1.791^{\star \star} \\
(-2.287)\end{array}$ & $\begin{array}{c}-1.881^{* * *} \\
(-3.036)\end{array}$ & $\begin{array}{l}-1.476^{*} \\
(-1.943)\end{array}$ & $\begin{array}{l}-1.791^{\star *} \\
(-2.166)\end{array}$ & $\begin{array}{l}-1.700^{* *} \\
(-2.533)\end{array}$ \\
\hline Structural reforms, Fiscal contraction \& Debt $<60$ & $\begin{array}{l}-0.0935 \\
(-0.271)\end{array}$ & $\begin{array}{c}-0.784 \\
(-1.199)\end{array}$ & $\begin{array}{c}-0.811 \\
(-1.553)\end{array}$ & $\begin{array}{l}-1.240^{* *} \\
(-2.214)\end{array}$ & $\begin{array}{c}-2.575 \\
(-1.643)\end{array}$ & $\begin{array}{c}-2.859 \\
(-1.583)\end{array}$ \\
\hline $\begin{array}{l}\text { Observations } \\
\text { Countries }\end{array}$ & $\begin{array}{c}260 \\
19\end{array}$ & $\begin{array}{c}260 \\
19\end{array}$ & $\begin{array}{c}260 \\
19\end{array}$ & $\begin{array}{c}260 \\
19\end{array}$ & $\begin{array}{c}249 \\
19\end{array}$ & $\begin{array}{c}237 \\
19\end{array}$ \\
\hline
\end{tabular}

Note: t-statistics in parentheses.

Conditional mean controls: Lagged change in yields, real GDP growth, lagged output gap, inflation, lagged overall fiscal balanceto-GDP, lagged public debt-to-GDP, lagged bilateral exchange rate vis-à-vis the $\$$ US, output loss due to banking crisis, and the smooth transition function associated with the change in cyclically-adjusted primary balance (fiscal stance).

${ }^{* * *} p<0.01,{ }^{* *} p<0.05,{ }^{*} p<0.1$. 
Table 9. Effect of Reform on Government Long-Term Yields

Dependent Variable: Deviation in long-term yields relative to pre-reform year

\begin{tabular}{|c|c|c|c|c|c|c|}
\hline & Year 0 & Year 1 & Year 2 & Year 3 & Year 4 & Year 5 \\
\hline Structural reforms, Fiscal expansion \& Debt>60 & $\begin{array}{c}-0.400 \\
(-0.778)\end{array}$ & $\begin{array}{c}2.622^{* * *} \\
(3.093)\end{array}$ & $\begin{array}{c}3.511^{* \star *} \\
(5.230)\end{array}$ & $\begin{array}{c}0.697 \\
(0.962)\end{array}$ & $\begin{array}{l}-2.665^{\star \star} \\
(-2.384)\end{array}$ & $\begin{array}{c}-4.343^{\star * \star} \\
(-3.940)\end{array}$ \\
\hline Structural reforms, Fiscal contraction \& Debt $>60$ & $\begin{array}{c}0.0362 \\
(0.0950)\end{array}$ & $\begin{array}{c}-3.318^{* * *} \\
(-4.033)\end{array}$ & $\begin{array}{c}-4.372^{* * *} \\
(-4.537)\end{array}$ & $\begin{array}{c}-3.821^{* * *} \\
(-3.387)\end{array}$ & $\begin{array}{c}0.842 \\
(1.180)\end{array}$ & $\begin{array}{l}2.960^{* *} \\
(2.394)\end{array}$ \\
\hline $\begin{array}{l}\text { Observations } \\
\text { Countries }\end{array}$ & $\begin{array}{c}180 \\
17\end{array}$ & $\begin{array}{c}180 \\
17\end{array}$ & $\begin{array}{c}180 \\
17\end{array}$ & $\begin{array}{c}180 \\
17\end{array}$ & $\begin{array}{c}166 \\
17\end{array}$ & $\begin{array}{c}153 \\
17\end{array}$ \\
\hline
\end{tabular}

Note: t-statistics in parentheses.

Conditional mean controls: Lagged change in yields, real GDP growth, lagged output gap, inflation, lagged overall fiscal balanceto-GDP, lagged public debt-to-GDP, lagged bilateral exchange rate vis-à-vis the $\$ U S$, output loss due to banking crisis, and the smooth transition function associated with the change in cyclically-adjusted primary balance (fiscal stance).

${ }^{* * *} p<0.01,{ }^{* *} p<0.05,{ }^{*} p<0.1$. 
Table 10. Effect of Reform on Government Long-Term Yields (AIPW)

Dependent Variable: Deviation in long-term yields relative to pre-reform year

\begin{tabular}{lcccccc}
\hline & Year 0 & Year 1 & Year 2 & Year 3 & Year 4 & Year 5 \\
\hline \multirow{2}{*}{ Structural reforms } & & & & & & \\
& $0.336^{* * *}$ & $-1.637^{* * *}$ & $-1.256^{* * *}$ & $-0.938^{* * *}$ & $-2.140^{* * *}$ & $-2.438^{* * *}$ \\
& $(3.227)$ & $(-7.717)$ & $(-4.796)$ & $(-2.834)$ & $(-5.022)$ & $(-5.538)$ \\
Observations & 440 & 440 & 440 & 440 & 440 & 440 \\
Countries & 21 & 21 & 21 & 21 & 21 & 21 \\
\hline
\end{tabular}

Note: t-statistics in parentheses.

Conditional mean controls: Lagged change in yields, real GDP growth, lagged output gap, inflation, lagged overall fiscal balance-to-GDP, lagged public debt-to-GDP, lagged bilateral exchange rate vis-à-vis the \$US, output loss due to banking crisis.

AIPW estimates do not impose restrictions on the weights of the propensity score.

${ }^{* * *} p<0.01,{ }^{* *} p<0.05,{ }^{*} p<0.1$. 
Table 11. Effect of Reform on Sovereign Ratings

Dependent Variable: Deviation in sovereign ratings relative to pre-reform year

\begin{tabular}{|c|c|c|c|c|c|c|}
\hline & Year 0 & Year 1 & Year 2 & Year 3 & Year 4 & Year 5 \\
\hline Structural reforms & $\begin{array}{l}-1.701^{*} \\
(-1.768)\end{array}$ & $\begin{array}{c}-0.939 \\
(-1.065)\end{array}$ & $\begin{array}{c}-0.945 \\
(-0.695)\end{array}$ & $\begin{array}{c}0.914 \\
(0.558)\end{array}$ & $\begin{array}{c}2.220 \\
(1.350)\end{array}$ & $\begin{array}{c}5.572^{* * *} \\
(4.597)\end{array}$ \\
\hline $\begin{array}{l}\text { Observations } \\
\text { Countries }\end{array}$ & $\begin{array}{c}491 \\
23\end{array}$ & $\begin{array}{c}491 \\
23\end{array}$ & $\begin{array}{c}491 \\
23\end{array}$ & $\begin{array}{c}468 \\
23\end{array}$ & $\begin{array}{c}445 \\
23\end{array}$ & $\begin{array}{c}422 \\
23\end{array}$ \\
\hline
\end{tabular}

Note: t-statistics in parentheses.

Conditional mean controls: Lagged change in yields, real GDP growth, lagged output gap, inflation, lagged overall fiscal balanceto-GDP, lagged public debt-to-GDP, lagged bilateral exchange rate vis-à-vis the $\$ U S$, output loss due to banking crisis.

${ }^{* * *} p<0.01,{ }^{* *} p<0.05,{ }^{*} p<0.1$. 
Table 12. Effect of Reform on Sovereign Ratings (AIPW)

Dependent Variable: Deviation in sovereign ratings relative to pre-reform year

\begin{tabular}{lcccccc}
\hline & Year 0 & Year 1 & Year 2 & Year 3 & Year 4 & Year 5 \\
\hline Structural reforms & & & & & & \\
& 0.378 & 0.471 & 0.180 & $2.389^{* * *}$ & $3.497^{\star * *}$ & $3.906^{* * *}$ \\
& $(1.115)$ & $(1.216)$ & $(0.502)$ & $(3.171)$ & $(5.649)$ & $(4.514)$ \\
Average change in rating values & 0.5 & 1.0 & 1.5 & 2.1 & 2.6 & 3.3 \\
Observations & 397 & 397 & 397 & 397 & 397 & 397 \\
Countries & 19 & 19 & 19 & 19 & 19 & 19 \\
\hline
\end{tabular}

Note: t-statistics in parentheses.

Conditional mean controls: Lagged change in yields, real GDP growth, lagged output gap, inflation, lagged overall fiscal balance-to-GDP, lagged public debt-to-GDP, lagged bilateral exchange rate vis-à-vis the $\$ U S$, output loss due to banking crisis.

AIPW estimates do not impose restrictions on the weights of the propensity score. ${ }^{* * *} p<0.01,{ }^{* *} p<0.05,{ }^{*} p<0.1$. 